\title{
Canada in Afghanistan: Concepts, Policies, Actors, and Prospects
}

\author{
David M. Law
}

\section{Introduction}

Canada's military involvement in the NATO campaign in Afghanistan has been of seminal importance for Canada in several respects. The Afghan campaign has been Canada's first foray into an active war-fighting environment since the Korean War. It signals the country's emergence as a nation that is ready to engage in heavy conflict if necessary, after decades of proudly wearing a peacekeeping mantle. This process has been accompanied by an effort on the part of Canada to return to the ranks of leading military nations after a sustained period of governmental neglect of the nation's defense capabilities. It has also been tragically marked by the proportionally highest casualty rate of any national actor in the post-2001 phase of conflict in Afghanistan, save Afghanistan itself.

If Canada's involvement in Afghanistan was sparked by a need to show its military solidarity with a traumatized post-9/11 United States, it has also brought in its wake conceptual and organizational changes in the way Canada goes about its activities in pursuit of development and reconstruction abroad. Afghanistan has initiated a long overdue debate about the nature and needs of effective development assistance, as well as about the overall relationship between development, security and justice. At the same time, the events of $9 / 11$ have had a significant impact on the country's understanding of governance, obliging politicians and bureaucrats in Ottawa to rethink the way the various federal departments engage in war zones and troubled states, and what this means for their interface in Ottawa. These trends have evolved in parallel with Canada's efforts at home to protect its population, infrastructure, and territory from terrorist attack and to deny the use of its territory for terrorist actions.

A number of conceptual innovations have accompanied these processes: the 3-D approach, the "whole of government" approach, and, in particular, Security Sector Reform (SSR), which will be the focus of this article. A later section of this article will examine these conceptual developments in detail, but first we will look at the factors that have driven and shaped change in Canadian thinking about security, development and governance in developing countries, including the strategic shift that occurred with 9/11. The article will also address the main features of Canada's SSR role in Afghanistan: what it has been doing in this theatre, how it has been pursuing its activities there, how its approach compares with that of other countries, and how Canada's efforts have

\footnotetext{
David Law is a Senior Fellow in the Operations Department and a Senior SSR Advisor to the International Security Sector Advisory Team (ISSAT) at the Geneva Centre for the Democratic Control of Armed Forces (DCAF). This article has been prepared with the assistance of Gabriel Real de Azúa, who has done much of the research and advised the author on successive drafts. His contribution is greatly appreciated.
} 
been conditioned by those of the international community in Afghanistan. The final section will put forward some recommendations for Canadian policymakers that may be also relevant for other countries facing similar circumstances.

\section{Drivers of Change}

In the Canadian context, several factors have combined to reshape how the country approaches security and how it views its relationship to development, justice and governance. This is a process that began in the early 1990s, but has received new impetus from several quarters in the more recent past.

With the end of the Cold War, Canada (like many other countries) began to reconceptualize its approach to security. This process involved Canada putting a new emphasis on the security of populations and the role of public security forces in this regard, and downplaying the bloc-to-bloc, state-focused security concerns and military issues that had dominated during the East-West conflict. At the same time, security perspectives that had previously been segregated into external and internal components began to collapse into a seamless continuum.

A second factor was the enhanced globalization of the security environment in the wake of the Cold War. Where previously the East-West confrontation had tended to marginalize conflicts in the developing world, in the changed strategic circumstances it rapidly became clear that a strategic problem virtually anywhere on the globe could have serious repercussions for a country's security. Canada, as a country traditionally open to trade and immigration, would increasingly find itself trying to cope with the impact of international information systems, global transportation flows, and ethnic and religious communities that are dispersed across countries and continents. Security globalization engendered a growing concern about the ability of fragile states and states in conflict to control their security forces and their borders, and to ensure that they would not become vehicles for the proliferation of weapons of mass destruction.

A third factor shaping the changes in Canada's view of global development was the country's experience with the failed states of the 1990s, in particular Haiti and Somalia, where Canadian troops were deployed in the largely failed international interventions of the early part of the decade. These deployments spotlighted the need for a secure environment if it was going to be possible to effectively deploy resources for development. This led to the emergence of what has come to be called the security-development nexus - that is, the notion that development is not possible without security, and that security can be neither provided nor sustained without development. Canada was an enthusiastic participant in the consultations undertaken by donors in the OECD Development Assistance Committee (OECD DAC) from roughly 1995 onward with a view to enhancing the effectiveness of donor assistance.

A fourth factor also emerged at mid-decade, when Canada, together with its NATO allies, began thinking seriously about the prospects of the organization enlarging to include the democratizing states of the former Warsaw Pact. As this process gathered steam, it became clear that it was not enough for the military forces of these countries to be efficient, effective, and professional; they also had to be democratically con- 
trolled and overseen if they were going to be capable of making a positive contribution to Alliance security, let alone not act as spoilers of the democratization process. At the same time, it was understood that NATO had to be similarly concerned with candidates' other security forces - the police, paramilitary agencies, intelligence services, and so on-which had traditionally represented a significant security threat to the population in communist countries. ${ }^{1}$ It was this realization that encouraged Canada to work with other member states of the OSCE, under EU leadership, to elaborate the OSCE Code of Conduct on Political-Military Aspects of Security, which entered into force in $1995 .^{2}$

The fifth driver of change came with the complex peace support operations in which Canada was involved during the second half of the 1990s in the former Yugoslavia. The deployment of Canadian troops in Bosnia-Herzegovina sent a number of very important messages. One message was that the traditional Canadian paradigm of peacekeeping - observing the peace between formerly belligerent parties — was already heavily discredited as an organizing principle for Canadian involvement in troubled states where a military contingent was deployed, and would in the future be the exception instead of the rule. Another message was that fundamental reform of a postconflict country's security sector was essential if a return to large-scale violence was to be prevented. In the case of Bosnia-Herzegovina - a new state that emerged out of the ashes of the Balkan conflict - this was particularly daunting challenge in view of the ethnic cleansing that had occurred during the war, the fragmentation along ethnic lines of the political structures prevailing in the country after the war, and the reflection of this in the organization of its security sector. An additional lesson drawn from the Bosnian experience was the need for viable systems to coordinate the policies and activities of the kaleidoscope of actors that tend to be active in post-conflict settings. In addition to national and regional governments, these include foreign donors, intergovernmental organizations, private military and security companies, and an army of nongovernmental organizations, both local and international. These were not entirely new phenomena for Canada to have to deal with, but this conflict was probably the first time that they had all come together so dramatically.

The sixth factor shaping Canada's approach was the transformation in strategic thinking provoked by the events of 11 September 2001 and the vulnerabilities they exposed in the United States' security posture. As the U.S. National Security Strategy admitted, a superpower's strategic self-understanding had been taken down for the

1 Saša Janković, "The Status of Serbia's Intelligence Reform and Its Challenges," in Security Sector Reform in South East Europe - from a Necessary Remedy to a Global Concept, ed. Anja H. Ebnöther, Ernst M. Felberbauer, and Mladen Staničić (Vienna: Austrian National Defense Academy and Bureau for Security Policy, 2007), 150-56; available at www.bmlv.gv.at/pdf_pool/publikationen/10_wg13_global-concept_200_jankovic.pdf.

2 David M. Law, "Rethinking the Code of Conduct in the Light of Security Sector Reform," in Consolidating the OSCE, ed. Daniel Warner, PSIO Occasional Paper 4 (2006): 83-105; http:/graduateinstitute.ch/webdav/site/iheid/shared/iheid/514/OP4_2006_EDITED_FINAL.pdf. 
price of a tank. ${ }^{3}$ Canada lost over thirty civilians in the 9/11 attacks but it was, of course, less concerned by their strategic implications than was the United States. On the other hand, it quickly understood that its vital trading relationship with the U.S. and the long (and at that time relatively unprotected) border over which goods, services, and people had to pass if Canada was to remain economically viable called for a series of measures to reinforce security, both at the border and internally. The subtext to this change in strategic approach was as follows: Canada's security forces needed to be retooled to deal with new strategic challenges, in particular those emanating from the confluence of such phenomena as failed states, weapons of mass destruction, and strategic terrorism; they needed more resources than they had had at their disposal through much of the previous half-century; and they needed to be able to work together as synergistically as possible.

Thus, Canada took measures to reinforce control of its border with the United States, including the arming of its previously unarmed custom officials. The immigration regime was reviewed to reduce the threat of foreign terrorists gaining entry to the country. There was a noticeable rapprochement with the United States on security issues under the Liberal government, one that was reinforced by its traditionally more pro-U.S. Conservative successors when they formed a minority government in 2006 after thirteen years in opposition. Funds devoted to defense were massively increased, rising by more than a quarter in 2007-08 compared with pre-9/11 levels and placing Canada as the sixth-highest military spender in NATO, well surpassing Canada's performance during the post-Korean phase of the Cold War. ${ }^{4}$ Relations among key ministries were reorganized, and a new Ministry of Public Safety was created, a Canadian version of the U.S. Department of Homeland Security. Overall, security issues were reintegrated into the mainstream of Canadian public and campus life ${ }^{5}$ after spending the better part of four decades out in the cold. ${ }^{6}$

Finally, the Canadian approach has also been shaped by the emergence in this decade of security sector reform as a policy framework in a growing number of its national

3 The National Security Strategy of the United States of America (Washington, D.C.: The White House, September 2002); available at www.whitehouse.gov/nsc/nss.pdf.

4 Steven Staples and Bill Robinson, "More Than the Cold War: Canada's Military Spending 2007-08," Foreign Policy Series 2:3 (Canadian Centre for Policy Alternatives, October 2007); available at http://www.policyalternatives.ca/documents/National_Office_Pubs/2007/ More_Than_the_Cold_War.pdf.

5 The author was involved in the efforts of the Department of National Defense to reintroduce lecturers from the military onto university campuses in 2001-02. The response of studentsmany of whom were first- or second-generation Canadians from fragile, conflict-torn, or post-conflict countries - was particularly enthusiastic.

6 Despite efforts to re-establish a credible security role for Canada at home and abroad, the process is still in its infancy and likely to take several years. For example, an article in the Toronto Globe and Mail under the heading of "Between the Lines of the Manley Report" by journalist Jeffrey Simpson (29 January 2008) claimed that the most soldiers that Canada - a member of the G8, with a population of 33 million people - was able to field at any one time was 1000 . 
development partners as well as key international organizations (IGOs) of which it is a member and with which it cooperates, such as the OECD DAC, the EU and the UN. For example, Canada was involved in the OECD DAC consultations that led to the elaboration of its Guidelines on Security System Reform and Governance in 2005 and the Handbook on SSR: Supporting Security and Justice in $2007 .^{7}$ It also played a key role in efforts underway at the United Nations as of 2005 to promote SSR in post-conflict settings. ${ }^{8}$ And, of course, as Canada has participated in these activities, its own thinking on SSR has evolved. As we shall see, the Canadian deployments to Afghanistan have tended to bring these factors together and, in several respects, have served to accentuate them.

\section{Box 1: Drivers of Change in the Canadian Approach to Security and Development}

1. Reconceptualization of the link between external and internal security

2. Security globalization

3. Security-development nexus

4. NATO enlargement

5. Third-generation peacekeeping

6. Strategic terrorism

7. Changes in partners' approaches

\section{Conceptual Frameworks}

Since the end of the Cold War, Canada has adopted four overarching frameworks for conceptualizing and orienting its activities on behalf of development and, in particular, on behalf of troubled states: human security, the 3-D approach, the "whole of government" approach, and security sector reform. While these concepts have entered the policy discourse at different intervals, they are not mutually exclusive. Instead, they tend to enjoy a certain level of simultaneous currency, and they all figure in varying degrees as mobilizing constructs for Canada's involvement in Afghanistan.

\section{Human Security}

The concept of Human Security (HS) was incorporated into Canadian foreign policy practice after 1993 when the Liberal party returned to government, looking for a conceptual framework to organize its actions abroad in the post-Cold War era. Under the

7 These documents are available at www.oecd.org/department/0,3355,en_2649_34567_1_1_ 1_1_1_,00.html.

8 See, for example, Geneva Centre for the Democratic Control of Armed Forces (DCAF), "The United Nations Approach to Security Sector/ System Reform (SSR) in Post-Conflict Peacebuilding: Review of Recent Experience of UN Integrated Missions in SSR Activities," available at www.dcaf.ch/un_ssr_pcpb/_index.cfm?navsub1=31\&nav1=3. 
leadership of a dynamic Foreign Minister, Lloyd Axworthy, it adopted a HS agenda as a way of underscoring that the purpose of its efforts abroad was to support populations in their efforts to live in security and under improving material and social conditions. In the Canadian vision, HS was not a substitute for state security; rather, state security was a precondition for the state meeting its responsibility to help populations live in freedom from both want and fear. As a manifestation of the attractiveness of this idea, a Human Security Network was established in 1999 with a dozen like-minded states from around the world. ${ }^{9}$ After the departure of Lloyd Axworthy from government in 2000, the HS star began to fade, although the Ministry of Foreign Affairs continues to fund projects under this heading. The weak point of HS has revolved around the question of how to operationalize the concept with robust programs in the field. ${ }^{10}$

\section{The 3-D Approach}

The so-called 3-D approach was adopted by the Liberal minority government in 2004 and incorporated into Canadian policy practice in 2005 with the publication of the country's new national security policy. ${ }^{11}$ This document sought to integrate external and public security issues, which in Canadian policy had traditionally been handled as separate and largely unconnected domains. Likewise, it called for the main Canadian departments that had traditionally been active in crisis settings - the Canadian International Development Agency (CIDA), the Ministry of Foreign Affairs and International Trade (DFAIT), and the Ministry of National Defense - to work closely together in the field (the implication being that this had not always been the case).

3-Dism has its limitations, however. In a 2007 speech, the Canadian Deputy Minister then responsible for coordinating government policy on Afghanistan observed that defense, diplomacy, and development are not parts that "equal the whole" in the sense that there needs to be "an overall policy construct that sits above 3-D" and that "motivates, validates, and connects everything" that Canada does. ${ }^{12}$ They need, moreover, to be approached not as distinct domains but as entirely inter-related ones, "as are (their) objectives and expertise...."

9 See www.humansecuritynetwork.org/menu-e.php.

10 It has been argued that human security was sidelined after 9/11 as Canada moved towards the U.S. approach in the War on Terror, which prioritized national security considerations as opposed to concerns about the security of individuals and their communities. See Stefan Gänzle, "The Impact on Human Security in Canada's Foreign Policy," available at www.cpsaacsp.ca/papers-2007/Ganzle.pdf. For an examination of the relationship between human security and SSR, see David M. Law, "Human Security and Security Sector Reform: Contrasts and Commonalities," Sicherheit und Frieden 1 (2005).

11 Canada's International Policy Statement, "A Role of Pride and Influence in the World: Defense" (2005); available at http://merln.ndu.edu/whitepapers/Canada_Defence_2005.pdf. The quotes are taken from a speech by David Mulroney entitled "Canada in Afghanistan: From Collaboration to Integration" delivered on 2 May 2007 when he was Canadian Associate Deputy Minister of Foreign Affairs and Interdepartmental Coordinator for Afghanistan. He has since become a Deputy Minister in the Privy Council Office, roughly the Prime Minister's dedicated civil service, with similar responsibilities. 
Beyond this, while the 3-D concept rests on an expanded vision of security, the actors to which it gives center stage are not capable of dealing with all the issues that need to be addressed in the field. Which of the 3-D departments identified above, for example, is to deal with policing, a crucial issue determining the success or failure of the international community's commitments to fragile and post-conflict states (the latest being Afghanistan)? Who is to deal with prisons? Or debt reduction? Or gender issues? And who would deal with all those other issues that are essential to putting a troubled or conflict-torn country back on its feet? Clearly, the 3-D approach falls short as a vehicle for mobilizing all the actors that matter in the Canadian development and security context - e.g., the Ministry of Finance, the Ministry of Public Safety, the Royal Canadian Mounted Police (RCMP), and Corrections Services Canada (CSC).

3-D has also been criticized in the Canadian context as a vehicle that attempts to camouflage the fact that funding for the deployments in Afghanistan has been heavily weighted in favor of the military, at the expense of development and diplomatic efforts. A 2006 report by a Canadian NGO claimed that defense spending has outpaced development funding by a factor of ten to one, while noting that the exact figures are difficult to come by. The numbers prompted Canada's former Minister of Foreign Affairs, Lloyd Axworthy, to quip that 3-D has become simply one big "D," i.e., defense. ${ }^{13}$

\section{The "Whole of Government" Approach}

The "whole of government" approach (WGA), sometimes also referred to as the "joined-up government" approach, was introduced in the Canadian discourse by the Conservative government that succeeded the Liberals in 2006 as an alternative of sorts to the 3-D approach. The concept is, however, rather different in nature. WGA revolves around the issue of what mechanisms can be devised to ensure that the various governmental actors involved in a particular issue area work together synergistically. This is a general problem for governments around the world and certainly not just in the area of security and development. It is a challenge in areas as diverse as health care, gender, and climate change, but the core problem is the same. The purposes for which a particular ministry was established - sometimes very early on in the Westphalian epoch - can be rendered irrelevant in part or whole by changing realties. When this happens, what do governments do in response? In the post-9/11 environment, does one create a new ministry - say, a ministry for security writ large? Does one establish a new framework for traditional actors to consult about new realties while preserving their individual prerogatives and structures? Or does one end up somewhere in between?

Canada, like the U.S., has embraced all three approaches in varying degrees. It has created a new Ministry (Public Safety); it has implemented new structures for inter-departmental consultation; and it has recently established a coordinating mechanism in the Prime Minister's office in an effort to ensure coherence and effectiveness on the part of the various governmental actors involved in Afghanistan. But as we shall see,

13 Taylor Owen and Patrick Travers, "3-D Vision," The Walrus (8 August 2008); available at www.walrusmagazine.ca/articles/2007.07.Afghanistan-and-Canada/. 
WGA is still much more an ambition than a norm: as the saying goes, "Whole of Government" can easily descend into "Hell of Government," with energies and resources being dissipated under the impact of coordinationitis and cooperationism. ${ }^{14}$ Much more thinking needs to be done on how to enhance the efficiency of mechanisms and methodologies for coordination and cooperation in environments at home and abroad where multiple governmental actors are active.

\section{Security Sector Reform}

$\mathrm{SSR}$, as with the other concepts under review here, is relatively new. The term was coined a decade ago by the British Minister of Development, Claire Short, and figured in the Canadian International Policy Statement of 2005. It, too, has emerged in response to the need to take a broader view of development and security, and to take better advantage of the joint insights that grow out of the interrelationships between their different policy communities.

The OECD DAC uses the term security system reform to highlight the notion that security needs to be approached from a broad perspective, and the term security and justice system reform to stress that justice is not to be considered as being subordinate to security, or to be subordinated to security considerations - to be securitized, as the discourse would have it. The more widely used term is security sector reform, which both the EU and the UN adopted when developing their SSR programs in response to the ground-breaking work of the OECD DAC, as have many donors in developing their national SSR agendas. We shall use SSR to denote both approaches, as their core propositions are virtually identical.

SSR has many manifestations and variants, but its key propositions can be reduced to three. One is the need to take a holistic approach to understanding the actors and factors involved in security, justice, development, and governance. A second is that security must be delivered professionally, efficiently, and at a reasonable cost (i.e., one that is commensurate with a country's resources). A third is that the security forces as well as the ministries that manage and direct them need to be subject to democratic control and oversight. This is essential if they are to be accountable, transparent, representative, and responsive - and in consequence to enjoy the confidence of the population, whose security should be their foremost concern. For an interpretation of the key norms pertinent to SSR, see Box 2 below.

SSR is versatile. It offers a framework for thinking about which actors play central or supporting roles in a country's security. It possesses a methodological dimension, for it insists on the need to take a comprehensive approach to the challenges of security, justice, development, and governance, and for security resources to be used for the public good. SSR holds, for example, that police reform should not proceed without the implications for justice and correctional institutions also being addressed, or that it

14 David M. Law, "Cooperation among SSR-relevant IGOs," in Intergovernmental Organisations and Security Sector Reform, ed. David M. Law (Berlin: Literal, 2007), 43-62; and David M. Law, "Taking Stock, Moving Forward," in Intergovernmental Organisations and Security Sector Reform, 239-52. 


\section{Box 2: Decalogue of Key SSR Norms ${ }^{15}$}

1. The security forces are capable of delivering security professionally, at a reasonable cost, and in a way that helps to ensure that justice for all individuals and groups in society is served.

2. The security sector is representative of the population as a whole. It is inclusive, adequately reflecting a country's various communities and fairly providing opportunities to both genders.

3. The security forces operate transparently. Information about their activities is accessible to the public, save where legitimate national security concerns justify keeping information classified.

4. A country's security objectives and policies are set out in a national security strategy and supporting documents that define the respective tasks and responsibilities of the various components of the security sector.

5. The executive and civil management authorities in charge of the security forces are capable of giving the security forces proper direction and management.

6. The security forces are overseen by (and accountable to) civilian, democratically constituted authorities. In particular, the legislature is empowered and able to oversee the policies and activities of the security forces as well as the executive and civil management authorities in charge of their activities.

7. The security forces operate within the rule of law.

8. Civil society and non-governmental actors with a role in monitoring the governance of the security sector are active and can operate independently.

9. Domestic security sector actors are capable of interfacing smoothly with one another.

10. Domestic security sector actors are well integrated into regional and international security frameworks.

can be deleterious for the population's security to build the capacity of security forces without ensuring that they are subject to democratic oversight and control. At the same time, SSR acts as a connector of a plethora of traditionally disparate policy strands: those of the security and development communities; the external actors supporting SSR and the implementing national governments; programs focusing on different actors or dimensions of security and development (e.g., police and military, security forces' performance, and oversight issues); regional, national, and local initiatives, and so on.

Thus, SSR goes substantially further than either the 3-D or WGA approaches. It takes a much broader approach to the question of which actors - external or domestic - should be involved in questions of security and development than does the 3-D approach. It also goes much further than does the notion of WGA, for example, in its insistence that it is not only important for government ministries to be joined up, but for a wide gamut of other actors as well, and that how different actors interface with

15 This material first appeared in David Law, "Taking Stock, Moving Forward," 248. 
one another is a decisive factor in their overall effectiveness. Unlike the 3-D and WGA approaches, SSR lays out key objectives for government action.

While the Canadian take on SSR has been largely inspired by the OECD DAC, Ottawa has tended to emphasize certain aspects that, while not at odds with OECD orthodoxy, take on a different accent. For example, DFAIT pairs SSR with the rule of law in the description it provides on its website, explaining that a security sector cannot be functional unless the rule of law prevails. ${ }^{16}$

The four concepts described above are often perceived as contrasting or even opposing elements. If we look at the core ideas behind them, however, we see that they are largely complementary. Figure 1 below attempts to capture this.

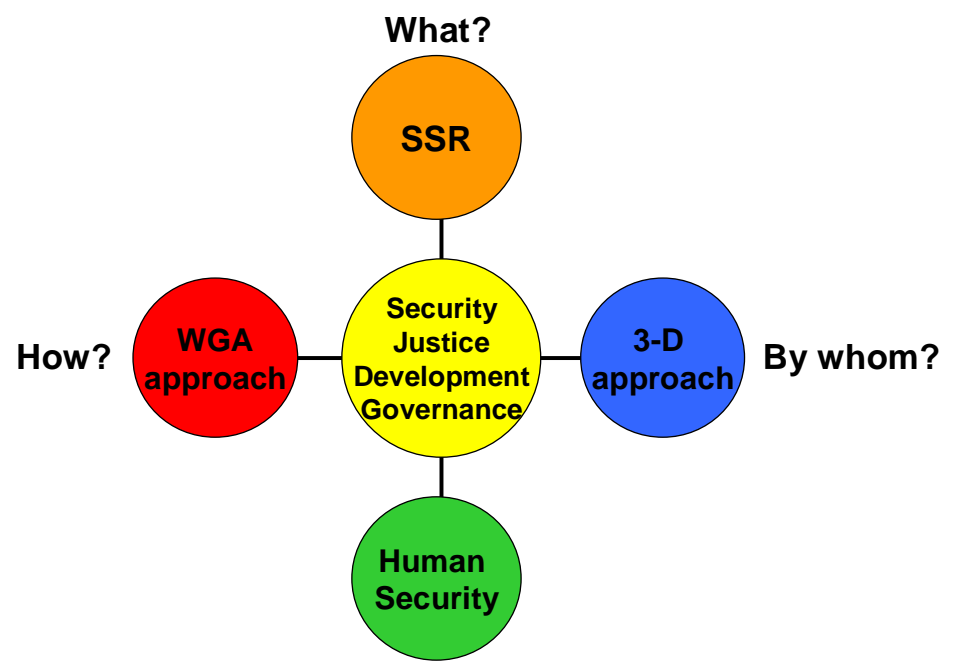

For whom?

Figure 1: Human Security, 3-D, Whole of Government, and SSR.

${ }^{16}$ See "Security System Reform and Rule of Law" at http://geo.international.gc.ca/cip-pic/ securitysystemreform-en.aspx and the statement of the Canadian Ambassador to the UN Security Council on 20 February 2007; available at www.canadaninternational.gc.ca/prmnymponu/canada.un-canada/statement.

As a developing concept, SSR has a number of dimensions that need further conceptual work, which would ideally be supported by empirical experience from the field. For example, the borders between what qualifies as SSR and what does not remain weakly defined. Is a train and equip program for the military SSR if it does not have a dimension designed to ensure that those who are trained and equipped are subject to effective democratic control? Or is this consideration moot if other actors are involved in governance issues that are designed to promote democratic governance? Likewise, the costs and benefits of SSR have not yet been subject to a rigorous comparative analysis. Furthermore, methodologies for assessing security sector performance or the effectiveness of SSR programs are still in their infancy. 


\section{Canada in Afghanistan}

\section{The Context}

Afghanistan, as is by now widely acknowledged, represents an extremely challenging environment for outside efforts that seek to support stability. The country is extremely poor, ranked 174 on the UNDP list of 178 nations in its Human Development Index. ${ }^{17}$ The median age in this country of 33 million is 17.6 years. Literacy rates are low, pegged at 43.1 percent for males and only 12.6 percent for females. The last figure available for unemployment, from 2005, is 40 percent. The country has no history of central governmental control over its territory and borders. It is ethnically diverse - its largest ethnic group, the Pashtuns, which make up some 42 percent of the population, are also the second-largest ethnic group in Afghanistan's neighbor to the south, Pakistan. Officially approved political parties number over eighty, yet there is little tradition of electoral competition. ${ }^{18}$

Afghanistan has known internal strife and conflict for over three decades at this point, provoked and/or exacerbated by a series of external interventions across its largely porous borders - most notably the Soviet invasion of 1979 and their ten-year presence before a humiliating withdrawal that helped spark systemic change in the USSR. The most prominent current incursion into Afghanistan from the outside world consists of Taliban elements from Pakistan supporting home-grown Taliban as well as Al Qaeda militants from around the Muslim world. Violence, which had largely subsided in the 2001-05 period, has since reappeared with a vengeance, as the overall situation in Afghanistan's larger region has deteriorated. It is against this background that countries as diverse as Canada and Germany have found themselves struggling to improve living conditions for the Afghan population and to help rebuild their state, a process that has involved nurturing a culture of governance that is largely new in the Afghan experience. ${ }^{19}$

\section{Canada's Objectives}

Canada's objectives in Afghanistan have varied little since the initial engagements involving Canadian troops in 2001-02 (despite the three changes of government that have taken place in Canada during this period). They are essentially four in number:

1. To prevent Afghanistan from again becoming a sanctuary for strategic terrorism

2. To support the UN peace enforcement mission for Afghanistan in accordance with Chapter VII of the UN Charter

17 See Afghanistan Human Development Report 2007 (Kabul: Center for Policy and Human Development, UNDP, 2007); at http://hdr.undp.org/en/reports/nationalreports/asiathepacific/ afghanistan/nhdr2007.pdf.

18 For a complete list of these, see https:/www.cia.gov/library/publications/the-world-factbook/ geos/af.html\#Govt.

19 See the entry on Afghanistan in the CIA World Factbook, accessible at https://www.cia.gov/ library/publications/the-world-factbook/print/af.html. 
3. To act in solidarity with Canada's allies in NATO (which represent twenty-six of the thirty-nine countries currently in the ISAF coalition)

4. To foster stability and development in Afghanistan, in keeping with Canada's general commitment to promoting human security in fragile states. ${ }^{20}$

A fifth objective, that of strengthening Canada's relationship with the United States, has also been apparent throughout this period, but particularly under the Conservative Government that has been in power since January $2006{ }^{21}$

Since 2001, Canadian governments have made five major decisions with respect to Afghanistan. All five decisions have been dominated by the security situation in the country and the need to secure a safe environment for reconstruction and governance capacity-building initiatives to proceed. The first decision was made in October 2001, under a Liberal majority government, when Canada deployed a Special Forces unit and 750 troops to Afghanistan to support the U.S. campaign there. At the same time, naval and air surveillance units were deployed to the Arabian Sea. The second decision came in February 2003, when 1700 ground troops were deployed to Kabul as part of the NATO-led International Security Assistance Force (ISAF). In March 2005, the third decision - this time under a Liberal minority government - was made when it was announced that the Canadian troops in Kabul would be redeployed to Kandahar in February 2006. After the Conservative Party came to power in January 2006, two more game-changing decisions were made. In May 2006, Parliament approved a two-year

${ }^{20}$ See "Independent Panel on Canada's Future Role in Afghanistan" (hereafter referred to as the Manley Report), available at http://dsp-psd.pwgsc.gc.ca/collection_2008/dfait-maeci/ FR5-20-1-2008E.pdf, especially 20-22.

${ }^{21}$ These objectives have been challenged by the Canadian public with essentially the following arguments:

- The money that is spent on or sent to Afghanistan would be better spent going to poor and disadvantaged Canadians.

- The deployment of Canadian troops costs too much.

- Canadian money is being spent on the Canadian military, not the Afghan military.

- Canadian resources should be invested in development, not counter-insurgency actions.

- Canada needs to revert to a traditional peacekeeping role (i.e., acting neutrally between opposing parties).

- In Afghanistan, Canada acts as a lackey of the United States; Canada has been bamboozled into a Global War on Terror that is based on false premises and/or ineffectively implemented.

- If Afghanistan is such an important issue, why are U.S./NATO allies contributing so few troops to ISAF and imposing constraints on them ("caveats") that make it difficult or impossible for the ISAF commander to deploy them flexibly to deal with security threats as they arise in various parts of Afghanistan?

- If Canada was not involved, the Afghans would have to do the job themselves.

- It would be better to spend Canadian money on other places, i.e., Darfur.

- Afghanistan is a lost cause; there is no point in pursuing the Canadian involvement there. 
Table 1: Overview of Canadian Military Involvement in Afghanistan.

\begin{tabular}{|c|c|c|c|c|c|}
\hline Government & $\overline{\text { Period }}$ & Command & $\begin{array}{c}\text { Forces } \\
\text { Deployed }\end{array}$ & $\begin{array}{c}\text { Theatre of } \\
\text { Deployment }\end{array}$ & $\begin{array}{c}\text { Lethality of } \\
\text { Environment }\end{array}$ \\
\hline $\begin{array}{l}\text { Liberal } \\
\text { majority }\end{array}$ & $\begin{array}{l}\text { As of } \\
\text { October } \\
2001\end{array}$ & $\begin{array}{l}\text { Canadian } \\
\text { Operation } \\
\text { Apollo; } \\
\text { Canadian } \\
\text { Naval Task } \\
\text { Group under } \\
\text { U.S. } \\
\text { Command } \\
\text { (OEF) }\end{array}$ & $\begin{array}{l}\text { (at peak) } 6 \\
\text { warships, } \\
1500 \text { Navy, } \\
\text { long-range } \\
\text { transport } \\
\text { aircraft, two } \\
\text { surveillance } \\
\text { and } \\
\text { maritime } \\
\text { patrol } \\
\text { aircraft }\end{array}$ & $\begin{array}{l}\text { Persian Gulf } \\
\text { / Arabian } \\
\text { Sea }\end{array}$ & $\begin{array}{l}\text { Relatively } \\
\text { benign } \\
\text { (zero } \\
\text { casualties) }\end{array}$ \\
\hline $\begin{array}{l}\text { Liberal } \\
\text { majority }\end{array}$ & $\begin{array}{l}\text { January- } \\
\text { August } 2002\end{array}$ & $\begin{array}{l}\text { U.S. } \\
\text { Command } \\
\text { (OEF) }\end{array}$ & 850 & Kandahar & $\begin{array}{l}\text { Still benign } \\
\text { but less so } \\
\text { (four } \\
\text { casualties) }\end{array}$ \\
\hline $\begin{array}{l}\text { Liberal } \\
\text { majority } \\
\text { and Liberal } \\
\text { minority as } \\
\text { of June } 2004\end{array}$ & $\begin{array}{l}\text { August } \\
2002- \\
\text { August } 2005\end{array}$ & $\begin{array}{l}\text { Operation } \\
\text { Athena; } \\
\text { NATO } \\
\text { Command } \\
\text { (ISAF) }\end{array}$ & 1700 & Kabul & $\begin{array}{l}\text { Relatively } \\
\text { benign } \\
\text { (three } \\
\text { casualties) }\end{array}$ \\
\hline $\begin{array}{l}\text { Liberal } \\
\text { minority }\end{array}$ & $\begin{array}{l}\text { August } \\
2005- \\
\text { January } \\
2006\end{array}$ & $\begin{array}{l}\text { U.S. } \\
\text { Command; } \\
\text { Canada } \\
\text { assumes } \\
\text { command of } \\
\text { K-PRT }\end{array}$ & 1000 & $\begin{array}{l}\text { Kabul to } \\
\text { Kandahar }\end{array}$ & $\begin{array}{l}\text { Relatively } \\
\text { benign } \\
\text { (one casualty) }\end{array}$ \\
\hline $\begin{array}{l}\text { Conservative } \\
\text { Minority as } \\
\text { of January } \\
2006\end{array}$ & $\begin{array}{l}\text { February } \\
2006- \\
\text { August } 2008\end{array}$ & $\begin{array}{l}\text { Operation } \\
\text { Archer } \\
(\mathrm{OEF}) \text { and } \\
\text { ISAF } \\
\text { Operation } \\
\text { Medusa; } \\
\text { NATO } \\
\text { command } \\
\text { (ISAF) }\end{array}$ & $\begin{array}{l}2000 ; \\
\text { increased to } \\
2500 \\
\text { between } \\
2006 \text { and } \\
2007\end{array}$ & Kandahar & $\begin{array}{l}\text { Increasingly } \\
\text { lethal } \\
\text { (eighty five } \\
\text { casualties) }^{22}\end{array}$ \\
\hline
\end{tabular}

22 Casualties current as of 25 August 2008. For an updated list of Canadian casualties, see www.cbc.ca/news/background/afghanistan/casualties/list.html. 
extension of the Canadian deployment. In January 2008, Parliament approved another extension - this time to 2011 - on the condition that an ally would provide an additional 1000 soldiers to support Canada's role in Kandahar. This followed the recommendations of a study commissioned by the government in October 2007 on Canada's future role in Afghanistan which, while critical, was supportive of the continuation of the mission.

Table 1 tracks the evolution of the Canadian presence in Afghanistan as a function of the government in power in Ottawa, the command to which the deployment has been subordinated, the number of Canadian personnel deployed and the lethality of the deployment environment.

\section{Public Opinion}

Opposition to Canada's involvement covers a broad range of concerns: the prospect of defeat, Canadian policy being subordinated to U.S. interests, burden-sharing, "Canada first" inclinations, and the need for Canada's involvement to be first and foremost about development and peacekeeping, not about war-fighting. ${ }^{23}$ These arguments are, however, not necessarily representative. The Canadian public has until recently tended

Table 2: Opinion Polls on Afghanistan.

Regarding Canada's military involvement in Afghanistan, do you... (\%) ${ }^{24}$

\begin{tabular}{|c|c|c|c|c|c|c|c|c|c|c|c|c|}
\hline & \multicolumn{2}{|c|}{2002} & \multicolumn{2}{|c|}{2004} & \multicolumn{2}{|c|}{$\begin{array}{l}2006 \\
\text { Mar }\end{array}$} & \multicolumn{2}{|c|}{$\begin{array}{l}2006 \\
\text { Jun }\end{array}$} & \multicolumn{2}{|c|}{$\begin{array}{l}2006 \\
\text { Oct }\end{array}$} & \multicolumn{2}{|c|}{$\begin{array}{l}2006 \\
\text { Nov }\end{array}$} \\
\hline Strongly approve & 38 & \multirow{2}{*}{75} & 26 & \multirow{2}{*}{61} & 21 & \multirow{2}{*}{49} & 25 & \multirow{2}{*}{56} & 23 & \multirow{2}{*}{48} & 19 & \multirow{2}{*}{50} \\
\hline Somewhat approve & 37 & & 35 & & 28 & & 31 & & 25 & & 31 & \\
\hline Somewhat disapprove & 11 & \multirow{2}{*}{33} & 15 & \multirow{2}{*}{35} & 16 & \multirow{2}{*}{48} & 15 & \multirow{2}{*}{40} & 18 & \multirow{2}{*}{50} & 18 & \multirow{2}{*}{48} \\
\hline Strongly disapprove & 12 & & 20 & & 32 & & 25 & & 32 & & 30 & \\
\hline
\end{tabular}

23 According to Janice Gross Stein and Eugene Lang, the initial deployment to Afghanistan was also conditioned by reluctance on the part of the Canadian (Liberal) government in the years following $9 / 11$ to participate in the modernization of NORAD, the U.S.-Canada system for monitoring aerial threats to North America into the U.S.-led Ballistic Missile Defense program. With the U.S. wanting to focus more of its hard power on Iraq, Canada was happy to fill the void in Kandahar. For a detailed account, see Janice Gross Stein and Eugene Lang, The Unexpected War: Canada in Kandahar (Toronto: Viking Canada, 2007), 181. Some observers, such as Duane Bratt, have argued that the third deployment, to Kabul in 2003, owed in part to Canada's desire to avoid a deployment to Iraq. Bratt also quotes the Canadian Ambassador to Washington explaining that the fourth deployment decision, in favor of Kandahar in 2005, was "...linked to the failure to send troops to Iraq in 2003."

${ }^{24}$ CBC-Environics; results available at www.cbc.ca/news/background/afghanistan/afghanistansurvey2006.html. 
to be more or less evenly divided in their attitudes towards Canada's role in Afghanistan - this, even into 2006, when Canadians began to suffer dramatically higher casualties. As a demonstration of this, while Canada has been in Afghanistan since late 2001, eighty five of its total of ninety three casualties have occurred in the last two years, essentially corresponding to its second deployment to Kandahar. Not surprisingly, there has been a corresponding drop in support for the Canadian mission over the last several years as well (see Table 2 above).

Skepticism as to whether the Canadian mission was worth pursuing was already quite pronounced in 2006, with almost 60 percent of Canadians polled doubting that it would succeed.

Do you think in the end the Canadian mission in Afghanistan is likely to be successful or not successful? $(\%)^{25}$

Successful 34

Not successful 58

Don't know/No answer 7

More recent polls show dwindling support. In a July 2008 poll conducted by Angus Reid Strategies, only 36 percent of Canadians agreed with the decision to extend Canada's military mission in Afghanistan through 2011. This was a sharp drop from a similar poll done in May 2008 which showed 41 percent. $^{26}$

\section{Actors}

Canada's involvement in Afghanistan has been played out through the actions and interactions of a bewilderingly complicated landscape of actors, as depicted in Figure 2 below. $^{27}$

The first set of actors involved in Canada's military deployment in Afghanistan is the array of Canadian government ministries in Ottawa - essentially Defense, Foreign Affairs, CIDA, Public Safety, Justice, and Finance - as well as other actors, such as the Canadian Parliament and its recently established Special Committee on Afghanistan. In addition to these governmental bodies, there are numerous coordinating mechanisms in Ottawa, both on the political and the working level:

- All the main departments of government involved in Afghanistan have an Afghanistan Task Force which until recently were coordinated through the Ministry of Foreign Affairs; in response to the Manley Report, the coordination

25 Ibid.

26 See www.cbc.ca/canada/story/2008/07/07/afghanistan-poll.html.

27 I am indebted to Jim Cox for his succinct rendering of this alphabet soup in "Afghanistan: The Canadian Military Mission," InfoSeries, Parliamentary Information and Research Service, Publication PRB 07-19E (6 November 2007). 
function has been relocated to the Privy Council, where it supports a newly created Cabinet Committee on Afghanistan. ${ }^{28}$

- START, the Stabilization and Reconstruction Task Force, is a crossdepartmental structure located in the Ministry of Foreign Affairs that is a major funder of Canadian activities in Afghanistan that are not clearly developmental in nature (financed through CIDA) or military in nature (financed through the Ministry of Defense). START primarily supports activities in the area of Rule of Law: police reform, judicial reform and prisons reform. ${ }^{29}$

- The SSR Working Group is another WGA mechanism embedded in DFAIT that since March 2006 has brought together functionaries from across government to ensure coherence in SSR policy, coordinate SSR deployments and ensure that those deployed on SSR missions have the requisite training.

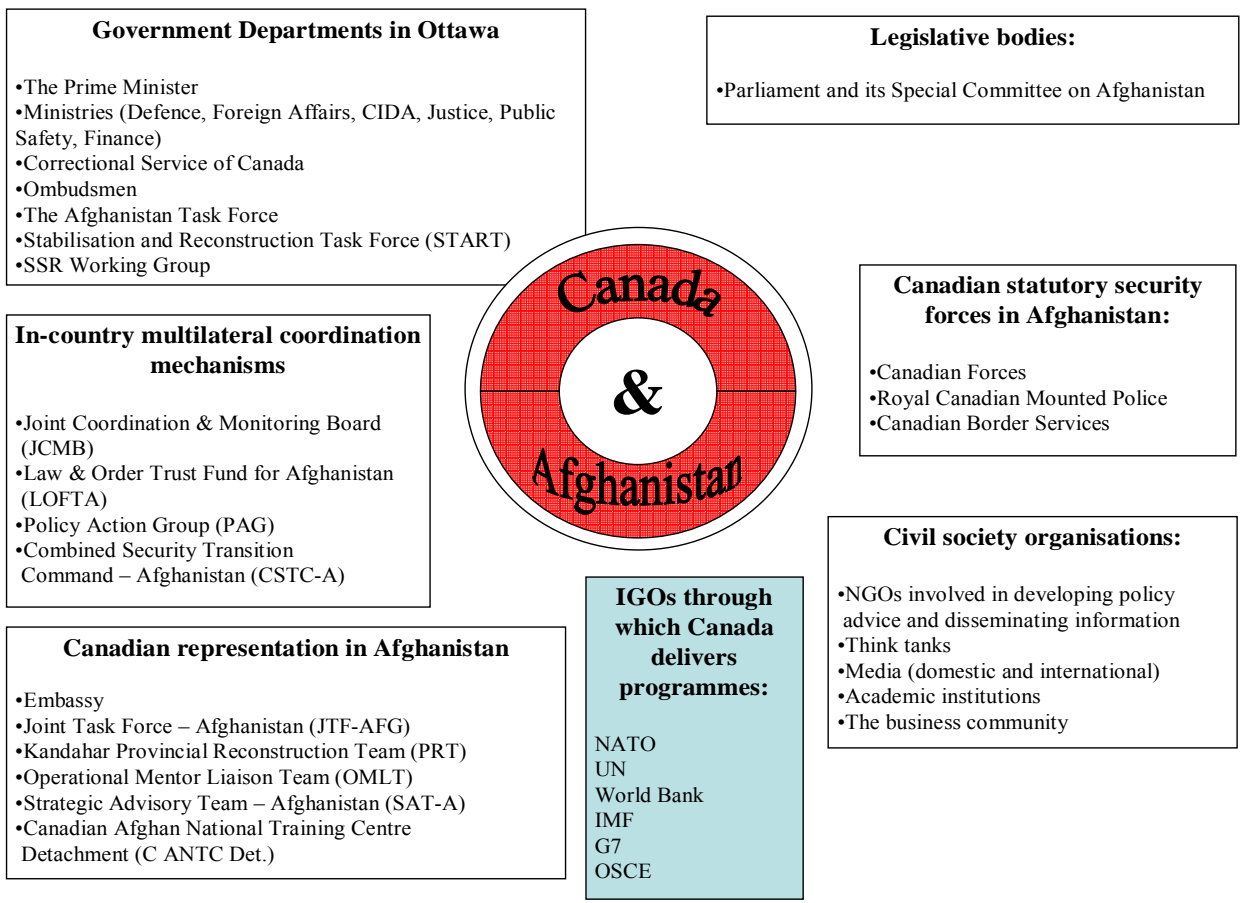

Figure 2: Actors Involved in Canada's Deployment in Afghanistan.

28 Prime Minister Harper announced the creation of the Cabinet Committee on Afghanistan and the Afghanistan Task Force within the Privy Council Office on 8 February 2008.

29 See www.international.gc.ca/START-GTSR/index.aspx. 
Another key set of actors consists of the intergovernmental organizations through which these departments deliver many of their policies and programs for Afghanistan, including NATO, the United Nations, the World Bank, the IMF, the G7, and the OSCE. The Canadian government interacts with these organizations both at their headquarters and in some instances through in-country offices and structures, such as NATO's International Security Assistance Force (ISAF), the United Nations Assistance Mission for Afghanistan (UNAMA), and the World Bank's Afghanistan Reconstruction Trust Fund. ${ }^{30}$

Another group of actors reflected above in Figure 2 includes various in-country multilateral coordination mechanisms, such as:

- The Joint Coordination and Monitoring Board (JCMB), which was set up in 2006 to oversee the implementation of the Afghanistan Compact - the road map for the country's further efforts in the areas of security, development, and governance-with seven representatives from the Afghan government and twenty-one from the international community, including Canada ${ }^{31}$

- The Law and Order Trust Fund for Afghanistan (LOFTA), created to finance priority policing activities ${ }^{32}$

- The Policy Action Group (PAG), established by President Karzai in 2006 to address in four working groups such issues as intelligence, security, strategic communication, and reconstruction and development; representation includes the Afghan President (who chairs the group); the Afghan ministers of defense, internal communications, and education; representatives of UNAMA, ISAF, and OEF; as well as the Ambassadors of the U.K., the Netherlands and Canada

- U.S.-led structures of which Canada is a part, such as the Combined Security Transition Command-Afghanistan (CSTC-A) that works with the Afghan government and the international community to help the Afghanistan National Security Forces carry out organizational reforms. ${ }^{33}$

The final set of actors reflected above in Figure 2 are the Canadian representatives in Afghanistan. These representatives include the Canadian Embassy, whose ambassador is the highest-ranking Canadian official in the country; the Joint Task Force-Afghanistan (JTF-AFG), now under NATO Command in ISAF and stationed in Kandahar, as well as special bodies with multi-departmental representation subordinated to them, such as the following:

${ }^{30}$ For information on the Trust Fund, see http://web.worldbank.org/WBSITE/EXTERNAL/ COUNTRIES/SOUTHASIAEXT/0,,contentMDK:21698820 pagePK:146736 piPK:146830 $\sim$ theSitePK:223547,00.html.

${ }^{31}$ Manley Report, 48.

32 Ibid.

${ }^{33}$ Manley Report, 47. 
- The Kandahar Provincial Reconstruction Team (KPRT), one of twenty-five PRTs operating in Afghanistan, which has roughly 350 personnel from various departments of government, protected by a dedicated Canadian Forces infantry company, whose task is to deliver reconstruction and development aid in Kandahar province, supported by a variety of international donors and contractors, including representatives of the United States Agency for International Development (USAID) and Afghan central ministries ${ }^{34}$

- The Canadian Operational Mentor Liaison Team (OMLT or, informally, omelette), which works with the Afghan Nation Army (ANA) and the Afghan Police to build capacity to a level where these national institutions can assume responsibility for security in Kandahar province ${ }^{35}$

- The Strategic Advisory Team-Afghanistan (SAT-A), which since 2005 has worked to support capacity-building for Afghan central ministries (while SAT-A is a military unit, it works closely with the Canadian ambassador, the CIDA representative in Kabul, and a senior representative of the Afghan government) ${ }^{36}$

- The Canadian Afghan National Training Center Detachment (CANTC Det) in Kabul, which provides some fifteen trainers for Afghan army personnel. ${ }^{37}$

Clearly, a major challenge to Canada has been to ensure a certain level of coherence in the objectives, programs, and actions of this army of actors. We will return to this challenge in the concluding section of this essay.

\section{SSR and SSR-related Program Activities}

The Canadian combat mission in Afghanistan has been the sine qua non for its SSRrelated activities in the country. The overarching framework for these activities is laid out in the Afghanistan Compact and the follow-on and more detailed Afghanistan National Development Strategy (ANDS), which has set out a five-year program of coop-

${ }^{34}$ Cox, "Afghanistan: The Canadian Military Mission."

35 Ibid.

${ }^{36}$ According to recent reports, the SAT-A unit is in the process of being disbanded and a new body, led by CIDA, is being constituted. This was one of the recommendations of the Manley Report.

${ }^{37}$ Not to be forgotten in this picture are the non-state actors that design programs and/or support their delivery. The first group of these includes the Canadian non-governmental organizations (NGOs) in both Canada and Afghanistan as well as the international non-governmental organizations (INGOs) and networks of which they are a part. For more information, see http://www.devp.org/devpme/eng/pressroom/documents/pdf/NGOProfiles.pdf. The second group includes private military and security companies (PMSCs). While to our knowledge Canada has no such companies operating in or for the Afghan theatre, the United States does - and such companies can have an impact on both civilian and military activities carried out by Canadians. Ongoing research at DCAF indicates that some ninety PMSCs are active in the Afghan theatre. 
eration between the government of Afghanistan and the international community in three areas: security; governance, rule of law, and human rights; and economic and social development (with counter-narcotics as a cross-cutting fourth program area). ${ }^{38}$ The activities of the main Canadian governmental departments engaged in Afghanistan have dovetailed closely with the first three of these program areas.

Thus, the Ministry of Defense and the Canadian military forces have played a leadership role on the cantonment of heavy weapons, demining and training the Afghan military. CIDA has taken the lead on infrastructure repair, rural development, education and local governance. The Ministry of Public Safety has been responsible for police training (through the Royal Canadian Mounted Police) and the improvement of prisons (through Corrections Services Canada, or CSC). ${ }^{39}$ The Ministry of Finance has been involved in many of these activities through World Bank, IMF and G7 funding mechanisms as well as other initiatives, such as providing advice to the Afghan government on trade and investment, private sector development, economic governance, DDR (disarmament, demobilization, and reintegration) programs and anti-narcotics actions.

The jewel in the crown in Afghanistan with respect to SSR, however, has been the work of the Provincial Reconstruction Teams. PRTs are civil-military partnerships designed to facilitate the development of a secure environment for reconstruction in the Afghan regions. PRTs are structured as civil-military partnerships. Only the military elements of PRTs are integrated in the ISAF chain of command. As described on the NATO website, the primary purposes of PRTs are the following:

- To help the government of Afghanistan extend its authority through the country

- To facilitate the development of a secure environment in the Afghan regions, including the establishment of relationships with local authorities

- To support, as appropriate (and within their means and capabilities), security sector reform activities in order to facilitate the reconstruction effort. ${ }^{40}$

Canada took over the Kandahar PRT from the U.S. in 2005-06, when it redeployed its troops from Kabul to Kandahar. It is top-heavy in military personnel owing to the security situation in the province, but the Canadian staff in Kandahar also includes representatives of Foreign Affairs, CIDA, the RCMP and the Canadian municipal police, Correctional Service Canada, as well as a few representatives of various U.S. agencies. ${ }^{41}$

38 These documents are available at http://www.ands.gov.af/admin/ands/ands_docs/upload/ UploadFolder/The Afghnistan Compact - Final English.pdf and www.diplomatie.gouv.fr/en/ IMG/pdf/Afghanistan_National_Development_Strategy_eng.pdf.

39 See Manley Report, $2 \overline{5}$ and "Canada in Afghanistan: Where the mission is and where it might go next," CBC News in Depth (22 January 2008).

40 This description is based on the information on the NATO website, at www.nato.int/issues/ afghanistan/040628-factsheet.htm.

41 Manley Report, 23. 
Currently, there are some twenty-five PRTs headed up by thirteen NATO member countries. The map in Figure 3 below shows their locations. ${ }^{42}$ Those that are led by the United States tend to downplay governance and emphasize security; most other PRTs focus on both development and governance issues. Some other PRTs, such as the one in Faryab led by Norway, focus on DDR and ANP training and mentoring. While similar to other PRTs in that it has military and civilian pillars, the Norwegian model is distinct because it does not engage directly in development work in its province but channels development funds through the Norwegian Embassy in Kabul, working in cooperation with two civilian employees from the embassy stationed at the PRT. In this way, the Norwegian PRT model is more centralized than others. ${ }^{43}$

\section{Budgets}

Canada spends more money on its efforts in Afghanistan than it does in any other country. ${ }^{44}$ Other countries identified as priorities for Canadian policy-such as Haiti and Sudan - lag well behind. According to the Canadian Broadcasting Corporation, the military costs for the mission in Afghanistan reached CDN 2.6 billion in March 2007 or nearly CDN 1.3 million per day of the mission. ${ }^{45}$ As in the case of U.S. spending for Iraq, assessments of the costs of military action vary widely. For example, one Canadian research organization has put the cost to date at three times as much. ${ }^{46}$

Canada is a leading donor to Afghanistan for civilian activities, with over one billion dollars pledged up to $2011 .^{47}$ Generally, estimates of the ratio of military to civilian costs run about ten to one. This proportion was criticized by the Manley Report, as has the fact that a great deal of Canadian spending goes through multilateral aid agencies (35 percent) and the central government (50 percent), leaving little funding for "locally-managed quick action projects that bring immediate improvement to everyday life for Afghans" or for "signature projects readily identified as supported by Canada., 48

There has also been criticism of the high proportion of contract budgets that stay with Canadian contractors as opposed to local Afghan actors, as well as the fact that the Afghan government has apparently been incapable of accounting for money put at its disposal. A recent article in the Canadian press claimed that Kabul had not been able to substantiate roughly one-third of the CDN 15 billion entrusted to it since $2001 .^{49}$

For a map and more information on the PRTs, see www.nato.int/multi/map-afghanistan.htm.

For more information on the Norwegian model, see www.norway.org.af/prt/faryab/.

Afghanistan is the single largest recipient of Canadian bilateral aid. Since 2002, Canada has contributed USD 412.2 million (18.8 percent of the total) through CIDA to the World Bankadministered Afghanistan Reconstruction Trust Fund (ARTF), making it the second largest contributor after the United Kingdom. See http://go.worldbank.org/OZ869X45T0.

Information accessed at www.cbc.ca/news/background/afghanistan/bythenumbers.html

www.globalresearch.ca/index.php?context=va\&aid=8590.

www.cbc.ca/news/background/afghanistan/bythenumbers.html.

Manley Report, 26.

Editorial, Globe and Mail (25 March 2008). 


\section{International Security Assistance Force}

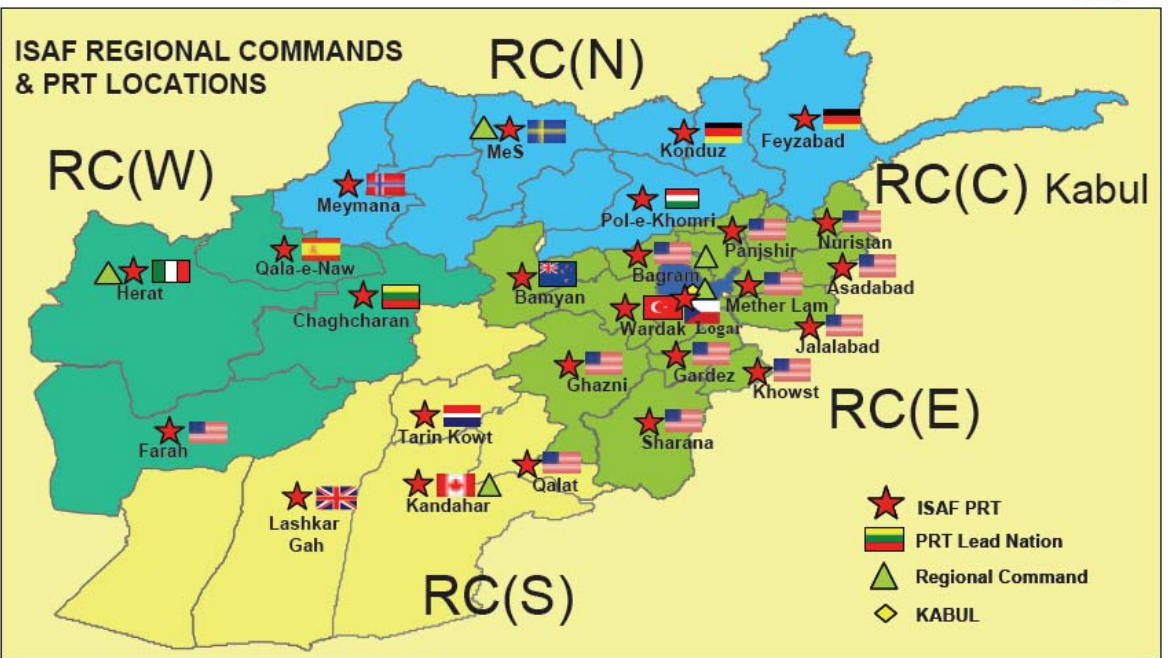

Figure 3: Location of Provincial Reconstruction Teams in Afghanistan.

Table 3: National Approaches to PRTs. ${ }^{50}$

\begin{tabular}{|c|c|c|c|c|}
\hline $\begin{array}{l}\text { Country/ } \\
\text { PRTs }\end{array}$ & $\begin{array}{l}\text { US } \\
(12)\end{array}$ & $\begin{array}{l}\text { UK } \\
\text { (1) } \\
\end{array}$ & $\begin{array}{l}\text { Germany } \\
(2)\end{array}$ & $\begin{array}{l}\text { CDN } \\
(1)\end{array}$ \\
\hline $\begin{array}{l}\text { Personnel } \\
\text { per PRT }\end{array}$ & 75 & 100 & 450 & 335 \\
\hline Composition & mainly military & civil-military & civil-military & civil-military \\
\hline Role & $\begin{array}{l}\text { focus mainly on } \\
\text { infrastructure repair: } \\
\text { small scale, quick impact } \\
\text { programs to win "hearts } \\
\& \text { minds" }\end{array}$ & $\begin{array}{l}\text { focus on both security } \\
\text { forces efficiency and } \\
\text { governance of security } \\
\text { sector (identified as } \\
\text { such as SSR) }\end{array}$ & $\begin{array}{l}\text { focus on both } \\
\text { security forces } \\
\text { efficiency and } \\
\text { governance of } \\
\text { security sector }\end{array}$ & $\begin{array}{l}\text { focus on both } \\
\text { security forces } \\
\text { efficiency and } \\
\text { governance of } \\
\text { security sector }\end{array}$ \\
\hline Environment & $\begin{array}{l}\text { eastern - } \\
\text { malign }\end{array}$ & $\begin{array}{l}\text { southern- } \\
\text { malign }\end{array}$ & $\begin{array}{l}\text { northern - } \\
\text { relatively benign }\end{array}$ & $\begin{array}{l}\text { southern - } \\
\text { malign }\end{array}$ \\
\hline
\end{tabular}

${ }^{50}$ For information on the German approach to PRTs, see "The German Concept of Provincial Reconstruction Teams (PRTs)," Doctrine 13 (October 2007): 104-107; available at www.cdef.terre.defense.gouv.fr/publications/doctrine/doctrine13/us/etranger/art8.pdf. 


\section{Policy Reorientation}

In follow-up to the aforementioned review of Canadian policy in Afghanistan, the Manley Report, Ottawa has published a report under the title "Canada's Engagement in Afghanistan: Setting a Course to 2011" (hereafter, Canada's Engagement). ${ }^{51}$ This report offers a candid assessment of the situation in Afghanistan. With respect to security, it notes that the situation deteriorated through 2007 and into 2008. Regarding governance, it decries persistent shortcomings owing to the weak capacity of Afghan government institutions and waning public trust because of continuing widespread corruption. In terms of development, Canada's Engagement acknowledges that, while the economy has been expanding at a remarkable rate, it will take many years of "sustained growth to reach reasonable levels." The report lays out a number of initiatives that have been undertaken in response to the Manley Report recommendations and others that go beyond it. These are summarized below.

First, Canada's Engagement revamps the government's governance approach to Afghanistan at home. As mentioned above and as recommended in the Manley Report, a Cabinet Committee on Afghanistan has been created and inter-departmental coordination of Canadian policy has been moved to the Privy Council from the Ministry of Foreign Affairs, with a dedicated full-time staff headed by deputy ministers from Foreign Affairs, Defense, Public Safety, and CIDA.

Second, Ottawa has committed itself to making quarterly reports to Parliament and its newly created Special Committee on Afghanistan, and to ensuring a better flow of information to the press and the Canadian public regarding its policy in Afghanistan. Ottawa has also promised to develop a system of benchmarks for measuring progress on the security, governance, and development fronts in Afghanistan, and on Canadian efforts in these regards.

Third, the Canadian approach within Afghanistan has been recalibrated in the direction of "Kandaharization" and "civilianization." The process of concentrating Canadian energies on Kandahar, initiated by the Liberal Party in 2005, will be reinforced. More resources will be allocated to the province, with the percentage of overall Canadian resources in Afghanistan that it is to receive rising from 17 percent to 50 percent. In conjunction with this increase, Canada will attempt to showcase three "signature" development projects in the province. Canada will continue to train Afghan police and military personnel, the objective being for them to be able to sustain a secure environment and rule of law by 2011 (the date when the Afghan Compact governing cooperation between the Afghan government and the international community is due to conclude, and when the Canadian presence will presumably wind down). A senior-level civilian representative is to be appointed to the PRT in Kandahar, and the overall number of Canadian civilians in the country is set to increase significantly. In-country, Canadian actors are to be given more discretion in making policy to address local conditions. In the country as whole, Canada is committed to pursuing its efforts to advance

51 Canada's Engagement in Afghanistan: Setting a Course to 2011 (Ottawa: Government of Canada, June 2008). 
Afghanistan's capacity for democratic governance and effective government decision making as well as helping to bring about national political reconciliation.

Fourth, Canada has put its NATO allies on notice that it expects them to field an additional one thousand combat troops if Canada is to maintain its own presence. This appeal is in part conditioned by the high number of Canadian casualties, but is also driven by the growing criticism leveled by the Afghan government towards coalition governments regarding civilian casualties owing to targeting errors from high-level bombing operations. Everything points to the fact that a shortage of soldiers on the ground necessitates greater use of air power which, while having greatly improved in accuracy in recent years, still remains a blunt instrument, often incapable of discriminating between Taliban and civilian targets at thousands of feet. ${ }^{52}$

Fifth, Canada's Engagement calls for a changed leadership paradigm for international efforts in Afghanistan, coming out strongly in favor of the United Nations assuming a much more important coordinating role in Afghanistan and enthusiastically supporting the appointment of the Norwegian Kai Eide as the UN Secretary-General's Special Representative in the country.

What to make of all this? While much of what is proposed appears to be very sound, Canada's Engagement raises more questions than it answers. The reorganization in Ottawa makes sense in theoretical terms, but it remains to be seen whether the now centrally located task force will have the necessary clout to make coherent policy and to implement it effectively. The degree of stove-piping in the Canadian departmental system (and in that of most other donor countries), despite 3-D and WGA efforts, remains considerable. The situation in and around Afghanistan - and in particular in such southern provinces as Kandahar - will have to contend with formidable political challenges in 2008-09: in particular, the instability and uncertainty engendered by elections in Pakistan, Afghanistan, the United States, and Canada itself. The call for additional support from NATO allies comes none too soon. But just how the Allies will respond remains to be seen, in view of reservations among their own publics and the material constraints they are under when it comes to putting soldiers in the field. Still, Allied countries deployed in more secure parts of the country and under restrictions to be active elsewhere are now under notice from Ottawa that this must change. Finally, there is definitely a need for enhanced coordination of the various initiatives underway in Afghanistan (and if anyone can finally make sense of the coordination challenges, the Norwegian diplomat Eide has the skills to do so). On the other hand, a UN umbrella under current international circumstances may not be the ideal framework for organizing the leadership of such a complex endeavor as Afghanistan.

\section{Assessment}

The Canadian approach to SSR in Afghanistan is some seven years old. What kind of balance sheet can now be established? Basically, the Canadians have attempted to take a comprehensive and integrated approach in their efforts, and have encouraged other

52 See, for example, "Afghan Civilians: Caught in the Crossfire," International Herald Tribune (7 September 2008); available at www.iht.com/articles/2008/09/07/opinion/edafghan.php. 
governments - donors as well as the Afghan government - to do likewise. A balance has been sought between governance initiatives and those seeking to enhance the ability of the Afghan security forces to assume responsibility for security delivery in the country on behalf of the population. These positive elements form an integral part of the current Canadian government's new approach to Afghanistan and should be accentuated as they are implemented. This being said, there is much that the Canadian government needs to do to in order to fully operationalize its approach to SSR, both in Afghanistan and more generally.

First, Canada should develop its own concept around SSR. This is not to suggest that Canada should try to reinvent the wheel in this regard. However, the country has a long tradition of involvement abroad that has been articulated and implemented through a variety of departmental policy portals with different operational cultures, objectives, operating procedures, and the like. These now need to be brought together in an overarching Canadian concept that is elaborated by the various Canadian government departments that are involved in SSR. More likely than not, such a concept will end up closely resembling the OECD DAC concept described above. But Canadians need to take ownership of their own national approach, and use this process to support efforts to encourage national actors to work together as part of a common endeavor.

Second, to this end, Canada should redouble its efforts to build the capacity of government representatives working both in Ottawa and abroad to operate in an SSR mode. Canada has been one of the first member countries of the OECD to engage in the capacity-building consultations on SSR offered by the OECD DAC. The Canadian experience in Afghanistan underscores the importance of having staff capable of supporting (and spearheading, as the situation may demand) the rebuilding or creation of ministries, security forces, and systems for managing government departments, their personnel and their finances, not to mention the all-important structures for overseeing and controlling the security forces and their masters.

Third, Canada needs to think about how to create incentives for its staff to coordinate and cooperate more effectively at home and in the field. The stance taken by government ministers, including the prime minister, is crucial in this regard. Beyond this, there is much that can be done to encourage synergies between different ministries at the staff level. Involving staff in the elaboration of inter-departmental MOUs would be a step in the right direction. Another would be the insertion of incentives in staff members' promotion packages that would reward efforts to enhance coordination and cooperation. Canada might also use its world-class International Development Research Center to explore new avenues for improving effective coordination and cooperation among the multiple actors that typically find themselves working shoulder to shoulder in such environments as Afghanistan.

Fourth, in view of the challenges discussed above, it may be worthwhile to think about creating dedicated international departments in those ministries that are called upon to provide capacity for programs, together with a policy framework for coordinating and integrating their efforts. As part of this process, Canada might review whether START - the centralized funding mechanism located in DFAIT — might not be 
more effective as a central fund of government subordinated to a central policy framework along the lines of the Afghanistan Task Force located in the Privy Council Office. Similarly, there should be a review of whether SSR and SSR-related funds now dispensed through CIDA and the Ministry of Defense should be reallocated to such a repositioned START. Centralization of funding is a device to which other governments, such as the United Kingdom and the Netherlands, have resorted with success. A related step in this area will be to rethink the way that international service is rewarded in the career paths of civil servants. The current system sometimes fails to take into account experience won in the field relative to experience gained in the corridors of power in Ottawa.

Fifth, Canada should redouble its efforts to encourage its Allies to step up to the plate. Already, the appeal for more troops has resulted in the French government deciding to deploy another seven hundred troops to Afghanistan. Canada has earned the credibility to demand more of its Allies. At the same time, Canada needs to pursue its efforts to be able to deploy military forces that can create a secure environment, carry out reconstruction efforts with and for local populations, and work together with other actors in the field, both military and civilian. If the experience of Western countries in Afghanistan since 2001 has shown nothing else, it has underscored the importance of being able to bring sufficient military forces to bear in order to create an environment in which development can proceed. It has also shown that the norm for development donors like Canada will often be to have to deal with environments that are both postconflict and conflictual in nature, whereby the borderlines between the two will often be ill-defined and subject to rapid change.

\section{Conclusions}

Canada has been an important player in Afghanistan, punching above its weight, particularly if one considers the development resources it has brought to the table and the military responsibilities it has assumed in the conflict in view of its traditional peacekeeping role. But Canada is only one actor in a broad coalition of other countries and their peace support forces, as well as NGOs, IGOs, PMSCs, and the local and international media (not to mention the Afghan government itself, whose role is of course crucial). It goes almost without saying that the fortunes of Afghanistan do not depend on Canadian efforts alone, just as Canada's successes and failures are in large part conditioned by those of other actors.

Much has been written about the trials and tribulations of the international community in Afghanistan and there is no need to revisit these debates in detail. ${ }^{53}$ But in

53 See Daniel Korski, “Afghanistan: Europe's Forgotten War,” European Council on Foreign Relations (January 2008); available at http://ecfr.3cdn.net/fcdc73b8da7af85936_q8m6b5o4j. pdf. See also Paul Gallis and Vincent Morelli, NATO in Afghanistan: A Test of the Transatlantic Alliance, CRS Report for Congress (Washington, D.C: Congressional Research Services, 18 July 2008); available at www.fas.org/sgp/crs/row/RL33627.pdf. And finally, see the International Crisis Group reports, accessible at www.crisisgroup.org/home/index.cfm?id= $1266 \& \mathrm{l}=1$. 
conclusion it may be useful to highlight the main shortcomings of the external actors' efforts.

A first observation is that, while the international community's involvement has not been tainted with the brush of illegitimacy, as it has in Iraq, this bonus has been losing relevance as the number of civilian casualties from aerial bombings has soared. There is a straight line between insufficient firepower to create a secure environment and over-reliance on air power to defeat the Taliban and Al Qaeda.

Second, the approach of the international community in Afghanistan has suffered from the beginning from the lack of a coherent strategy. Any effort in this direction was skewered from the outset by two things: the preponderance of the U.S.-led agenda of the Global War on Terror in determining the policies of the international community, but also the piecemeal approach to Afghan security that was institutionalized by the decisions made at the Bonn donors' conference in 2002. The strategic malaise goes well beyond this, however; it has included an abject failure to think creatively about how to give the Pashtuns-Afghanistan's largest ethnic group — a stake in the country's stabilization and development. If the Sunnis of Iraq can be brought back into the fold, why cannot the Pashtuns of Afghanistan? A related strategic issue concerns how the international community has approached other players in Afghanistan's region-most obviously Pakistan, but also others such as Iran, India and the Central Asian republics.

A third major fault line has concerned the ability of the myriad of actors involved in Afghanistan to work together. Examples of dysfunctional relationships are legend. To take just a few, there are the efforts of the international community to promote the rule of law in Afghanistan. It is clear that programs in the related areas of policing, courts, and corrections are uncoordinated. It is clear that approaches to these policy areas differ from province to province and from district to district as a function of which external donor is in the lead. These donors tend to propagate the norms and objectives that they are most familiar with from their own national practice. There are as yet no common international reference points for reform efforts. What happens on the district and provincial level tends to be disconnected from what happens on the national level, and in turn there is little interface between programs concerning policing and those that address the military, notwithstanding the interdependence of these two sub-sectors of the security sector in providing for the public's security in Afghanistan. ${ }^{54}$

Last but not least, there is the issue of resources. Afghanistan is Iraq's poor sister in this regard, with the latter profiting from substantially greater resource inputs from abroad and more recently also from internally generated resources such as oil. Iraq is currently home to over 160,000 troops, while Afghanistan-with a territory several times larger than Iraq and with a much more challenging topography—only has 47,000 troops in total.

Afghanistan has proven to be a major testing ground for a number of opposing approaches championed by different stakeholders in the Canadian context. One has re-

54 Such shortcomings were at the core of a workshop on policing and justice issues organized by the Canadian Mission to the EU in Brussels on 1 April 2008. 
volved around what is the best use of the Canadian Forces - in particular, the issue of whether they should uphold their traditional post-Korean War role as peacekeepers, or whether they need to be capable of participating in combat operations as they have been required to do in Afghanistan. This deployment has also seen Canada struggling with a choice between its more traditional stance as an ally that fell into line and one that is now prepared, when pressed, to set conditions for other allies to fulfill. A third area of challenge has involved the government's public information policy, whereby the choice has been between the continuation of longstanding efforts to control the public debate by attempting to seal issues off from public scrutiny to a more recent attempt to engage parliament and the public through regular reporting on developments and the accompanying implicit invitation for them to exercise greater oversight.

Alongside such general public policy issues, debates that are more specific to the SSR agenda have raged as well. In particular, there is the question of the proper mix between long-term development programs (such as those sponsored by CIDA) and shorter-term, quick-fix, rapid results projects as advocated by the Ministry of Defense and the Canadian Forces. The response for the time being appears to be that both are needed and that, if the latter are particularly required, they should be embedded in a long-term development perspective. Also dear to the SSR agenda has been the question of inter-governmental coordination and cooperation, where much progress has been made, even if much more is called for. Finally, in recent years, Canada has moved towards a comprehensive, integrated approach to security and development, justice, and governance. The movement has been slow, incomplete, and imperfect, but it has definitively taken place. This is a promising trajectory that warrants continuing support on the part of both the Canadian public and Canada's partners. 


\section{Bibliography}

A Role of Pride and Influence in the World: Defense. Canada's International Policy Statement, 2005.

Afghan Civilians: Caught in the Crossfire. International Herald Tribune (2008).

Afghanistan Human Development Report 2007. Kabul: Center for Policy and Human Development, UNDP, 2007.

Canada in Afghanistan: Where the mission is and where it might go next. CBC News in Depth, 2008.

Canada's Engagement in Afghanistan: Setting a Course to 2011. Ottawa: Government of Canada, 2008.

Cox, Jim. Afghanistan: The Canadian Military Mission In InfoSeries, Parliamentary Information and Research Service, Publication., 2007.

Gallis, Paul. "NATO in Afghanistan: A Test of the Transatlantic Alliance." Connections: The Quarterly Journal 6, no. 3 (2007): 10-32.

Gänzle, Stefan. The Impact on Human Security in Canada’s Foreign Policy., 2007.

Independent Panel on Canada's Future Role in Afghanistan” (Manley Report)., 2008.

Janković, Saša. "The Status of Serbia's Intelligence Reform and Its Challenges." In Security Sector Reform in South East Europe - from a Necessary Remedy to a Global Concept, 150-56. Vienna: Austrian National Defense Academy and Bureau for Security Policy, 2007.

Korski, Daniel. Afghanistan: Europe's Forgotten War. European Council on Foreign Relations, 2008.

Law, David M.. "Cooperation among SSR-relevant IGOs." In Intergovernmental Organisa-tions and Security Sector Reform, 43-62. Berlin: Literal, 2007.

Law, David M.. "Rethinking the Code of Conduct in the Light of Security Sector Reform." In Consolidating the OSCE, 83-105., 2006.

Law, David M.. Human Security and Security Sector Reform: Contrasts and Commonalities. Sicherheit und Frieden, 2005.

Owen, Taylor, and Patrick Travers. "3-D Vision." The Walrus (2008).

Staples, Steven, and Bill Robinson. More Than the Cold War: Canada's Military Spending 2007-08 In Foreign Policy Series. Vol. 2. Canadian Centre for Policy Alternatives, 2007.

Stein, Janice Gross, and Eugene Lang. The Unexpected War: Canada in Kandahar. Toronto: Viking Canada, 2007.

The German Concept of Provincial Reconstruction Teams (PRTs). Doctrine 13 (2007): 104-107.

The National Security Strategy of the United States of America., 2002. 
The United Nations Approach to Security Sector/ System Reform (SSR) in Post-Conflict Peacebuilding: Review of Recent Experience of UN Integrated Missions in SSR Activities. Geneva: Geneva Centre for the Democratic Control of Armed Forces (DCAF), 2007. 